ISSN. 2775-4324 (Online)

Journal of Physical Activity and Sports (JPAS)

Volume 2, Nomor 1, April 2021, 130-138

Journal of Physical Activity and Sports

\title{
Analisis Gaya Hidup Sehat Siswa Kelas XII SMAN 14 Semarang di Era Pandemi Covid-19
}

\author{
Fitrian Rama Aditya ${ }^{1}$, Maftukin Hudah ${ }^{2}$, Utvi Hinda Zhannisa ${ }^{3}$ \\ Universitas Pgri Semarang. Jln Gajah Raya No 40. 50166
}

Email : ramaaditya97.ra@gmail.com, maftukinhudah10@upgris.ac.id, utvihindazhannisa@upgris.ac.id

Received: 23-12-2020; Revised: 24-12-2020; Accepted: 29-04-2021

\begin{abstract}
The Covid 19 pandemic that occurred in Indonesia caused concern for students. Efforts that can be made to reduce the risk of contracting Covid 19 are adopting a healthy lifestyle. The purpose of this study was to determine the application of a healthy lifestyle for class XII students of SMA Negeri 14 Semarang in the era of the COVID-19 pandemic. This research uses qualitative research with a descriptive approach. The research subjects were students of class XII SMA Negeri 14 Semarang. Collecting data using interview, observation and documentation methods. Data analysis used methods carried out by data reduction, data presentation and drawing conclusions. The results of the study: 1) The use of masks has been applied well. 2) Maintaining cleanliness is carried out well in terms of efforts to maintain personal and environmental hygiene. 3) The implementation of keeping the distance has not been maximally seen from the students who are still clustered. 4) The level of awareness of students to consume balanced nutrition is good, but there are obstacles such as the income factor of parents. 5) The implementation of physical activity has been done by most of the students. 6) The implementation of adequate rest has not been done with less than optimal. 7) The smoking habit was only done by a few students. None of the students consumed alcoholic beverages. Based on the results of the study, it can be concluded that the application of a healthy lifestyle for class XII SMA Negeri 14 Semarang has been going quite well..
\end{abstract}

Keyword : Healthy Lifestyle, High School Students, Pandemic Covid-19

\begin{abstract}
Abstrak
Pandemi covid 19 yang terjadi di Indonesia menimbulkan kekhawatiran bagi siswa. Upaya yang dapat dilakukan untuk mengurangi risiko tertular covid 19 adalah menerapkan gaya hidup sehat. Tujuan dari penelitian ini adalah mengetahui penerapan gaya hidup sehat siswa kelas XII SMA Negeri 14 Semarang di era pandemi covid 19. Penelitian ini menggunakan penelitian kualitatif dengan pendekatan deskriptif. Subjek penelitian yaitu siswa kelas XII SMA Negeri 14 Semarang. Pengumpulan data menggunakan metode wawancara, observasi dan dokumentasi. Analisis data menggunakan metode yang dilakukan dengan reduksi data, penyajian data dan penarikan kesimpulan. Hasil penelitian : 1) Penggunaan masker sudah diterapkan dengan baik. 2) Menjaga kebersihan terlaksana dengan baik dilihat dari upaya untuk menjaga kebersihan diri dan lingkungan. 3) Penerapan jaga jarak belum maksimal dilihat dari siswa yang masih berkerumun. 4) Tingkat kesadaran siswa untuk mengonsumsi gizi seimbang sudah baik, tetapi terdapat hambatan seperti faktor pendapatan orang tua. 5) Penerapan aktivitas fisik sudah dilakukan sebagian besar siswa. 6) Penerapan istirahat yang cukup belum dilakukan dengan kurang maksimal. 7) Kebiasaan merokok hanya dilakukan beberapa siswa. Tidak ada siswa yang mengonsumsi minuman beralkohol. Berdasarkan hasil penelitian dapat disimpulkkan bahwa penerapan gaya hidup sehat siswa kelas XII SMA Negeri 14 Semarang sudah berjalan dengan cukup baik.
\end{abstract}

Kata kunci: Gaya Hidup Sehat, Siswa SMA, Pandemi Covid-19

\section{PENDAHULUAN}

Olahraga memiliki peran penting dalam kehidupan manusia. Olahraga yang dilakukan secara rutin berdampak baik terhadap kesehatan yang membuat tubuh sehat dan bugar. Menurut Utomo (2015:2) olahraga merupakan bagian dari kehidupan manusia sepanjang masa. Sepanjang masa 
mengandung pengertian berawal dari kapan manusia itu ada dan akan berakhir bila manusia itu selalu ada.

Sistem pendidikan di dunia saat ini terganggu oleh adanya pandemi. Novel coronavirus atau sering disebut virus corona merupakan penyebab pandemi yang sedang terjadi. Menurut Kemenkes (2020) coronavirus adalah keluarga besar virus yang menyebabkan penyakit mulai dari gejala ringan sampai berat. Ada setidaknya dua jenis coronavirus yang diketahui menyebabkan penyakit yang dapat menimbulkan gejala berat seperti Midle Eas Respiratory Syndrome (MERS) dan Severe Acute Respiratory Syndrome (SARS). Coronavirus Disease 2019 (covid 19) adalah penyakit jenis baru yang belum pernah diidentifikasi sebelumnya pada manusia. Virus penyebab covid 19 ini dinamakan sarscov-2. Virus corona adalah zoonosis (ditularkan antara hewan dan manusia). Tanda dan gejala umum infeksi covid 19 antara lain gejala gangguan pernafasan akut seperti demam, batuk dan sesak nafas. Masa inkubasi rata-rata 5-6 hari dengan masa inkubasi terpanjang 14 hari. Pada kasus covid 19 yang berat dapat menyebabkan pneumonia, sindrom pernafasan akut, gagal ginjal dan bahkan kematian.

Indonesia merupakan salah satu Negara yang merasakan dampak dari pandemi di sektor pendidikan. Berdasarkan Surat Edaran Nomor 4 Tahun 2020 Tentang Pelaksanaan Kebijakan Pendidikan Dalam Masa Darurat Penyebaran Coronavirus Disease (Covid-19) (2020) menyatakan bahwa proses belajar dilakukan dari rumah. Nantinya pembelajaran akan dilakukan dengan sistem daring. Kebijakan tersebut berlaku untuk seluruh lembaga pendidikan di Indonesia. Hal ini dilakukan sebagai upaya mencegah penularan virus covid 19. Pelaksanaan pendidikan di Kota Semarang dilakukan secara daring sesuai dengan arahan Kemendikbud yang berlaku untuk semua jenjang Pendidikan. Meskipun pembelajaran dilakukan melalui sistem daring tetapi bahaya dari virus covid 19 masih mengancam siswa.

Masa pandemi covid 19 di Indonesia telah merubah kebiasaan masyarakat, termasuk siswa. Dalam melakukan aktivitas sehari-harinya harus mematuhi protokol kesehatan yang sudah di tetapkan. Menurut Keputusan Menteri Kesehatan Republik Indonesia Nomor Hk.01.07/Menkes/382/2020 tentang Protokol Kesehatan Bagi Masyarakat (2020) protokol kesehatan yang harus diterapkan adalah menggunakan alat pelindung diri berupa masker yang menutupi hidung dan mulut hingga dagu, membersihkan tangan secara teratur cuci tangan, menjaga jarak minimal satu meter dengan orang lain dan meningkatkan daya tahan tubuh.

Penerapan protokol kesehatan ini sebagai upaya pencegahan penularan virus covid 19. Selain itu, gaya hidup yang kita jalankan selama pandemi juga sangat berpengaruh. Apabila kita menjalankan gaya hidup sehat dengan teratur dan baik maka kita dapat mengurangi risiko tertular dari virus penyakit, khususnya virus covid 19. Gaya hidup sehat sendiri yaitu perilaku dan kegiatan yang berkaitan dengan upaya mempertahankan dan meningkatkan kesehatan sehingga mempengaruhi tingkat kebugaran jasmani (Arfianto 2017:2). Gaya hidup sehat mempunyai peranan yang penting untuk meningkatkan kesehatan setiap individu. Tubuh sehat pada masa pandemi merupakan dambaan setiap orang dengan tubuh yang sehat seseorang dapat melakukan aktivitas sehari-hari tanpa ada 
gangguan.

Berdasarkan uraian permasalahan di atas layak untuk dikaji lebih lanjut melalui sebuah penelitian dengan judul "Analisis Gaya Hidup Sehat Siswa Kelas XII SMA Negeri 14 Semarang Di Era Pandemi Covid-19". Penelitian ini memiliki tujuan untuk mengetahui gaya hidup sehat siswa kelas XII SMA Negeri 14 Semarang di era pandemi covid 19.

\section{METODE}

Penelitian ini menggunakan penelitian kualitatif dengan pendekatan deskriptif yang bertujuan untuk mengetahui dan mengkaji lebih dalam tentang penerapan gaya hidup sehat siswa kelas XII SMA Negeri 14 Semarang di era pandemi covid 19. Subjek penelitian yaitu siswa kelas XII SMA Negeri 14 Semarang. Penentuan subyek dilakukan secara simple random sampling. Menurut Sugiyono (2014:120) simple random sampling adalah teknik pengambilan sampel yang dilakukan secara acak tanpa memperhatikan strata. Dalam penelitian ini, terdapat 2 kelas yang terpilih untuk dijadikan sumber data penelitian yaitu kelas XII MIPA 3 dan XII IPS 1. Pengumpulan data menggunakan metode wawancara, observasi dan dokumentasi. Analisis data menggunakan cara reduksi data, penyajian data, penarikan kesimpulan dan verifikasi.

\section{HASIL DAN PEMBAHASAN}

\section{Penggunaan Masker}

Penggunaan masker menjadi sesuatu hal yang sangat penting di era pandemi covid 19. Penggunaan masker ini berguna untuk mengurangi risiko tertular virus corona. Oleh karena itu penggunaan masker diwajibkan untuk semua orang termasuk siswa kelas XII SMA Negeri 14 Semarang. Bahkan penggunaan masker termasuk ke dalam protokol kesehatan yang sudah ditetapkan oleh pemerintah untuk diterapkan dengan baik. Berikut petikan wawancara peneliti dengan siswa :

AKR : "Penggunaan masker di masa sekarang itu penting, karena untuk menjalankan protokol kesehatan dan untuk menjaga kesehatan agar tidak tertular virus covid 19".

SKB :"Penggunaan masker itu penting karena dengan menggunakan masker kita bisa memutus penularan virus covid".

RR : "Penggunaan masker untuk melindungi diri dan mencegah agar kita tidak terkena virus corona"

Kesadaran tentang pentingnya menggunakan masker di era pandemi covid 19 sudah tertanam di siswa SMA Negeri 14 Semarang. Pernyataan ini selaras dengan hasil wawancara dengan siswa mengenai penggunaan masker secara rutin. Hal tersebut dapat dilihat dari distribusi diagram di bawah ini : 


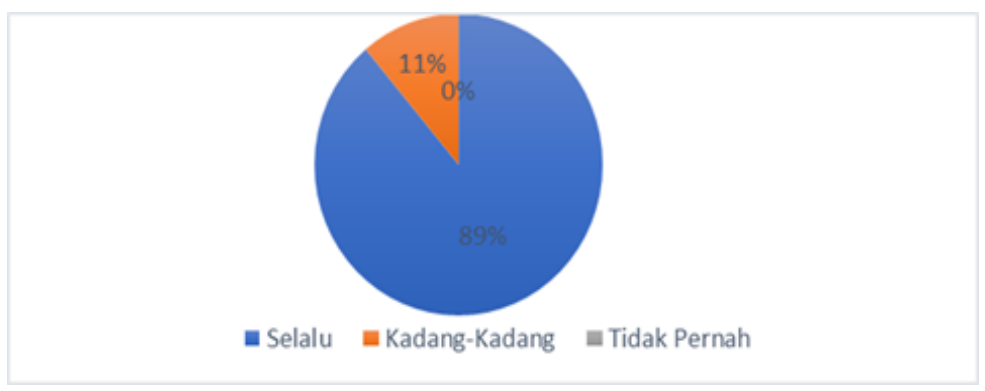

Gambar 1. Diagram Penggunaan Masker Siswa

\section{Menjaga Kebersihan}

Menjaga kebersihan sejak dari dulu sudah dianggap menjadi suatu hal yang penting. Menjaga kebersihan dapat menjaga diri kita tetap sehat dan terhindar dari penyakit. Sebab bakteri dan virus mudah menyebar dan jika kita tidak menjaga kebersihan diri kita maka kita kemungkingkan akan terserang penyakit. Berikut petikan wawancara peneliti dengan siswa :

IAF : "Menjaga kebersihan itu penting, kalo kita nya sudah bersih, kuman atau bakteri tidak bisa menempel di tubuh kita, jadi kita bisa mengurangi risiko terkena penyakit"

FN : "Dengan menjaga kebersihan, tubuh kita menjadi bersih dan kuman serta bakteri penyakit akan mati jadi kita aman dari penyakit"

AAS : "Karena kebersihan sebagian dari iman jadi kita wajib menjaga kebersihan, selain itu dengan menjaga kebersihan kita bisa membunuh kuman penyakit".

Siswa sudah mengetahui tentang apa yang harus dilakukan untuk menjaga kebersihan diri dan kebersihan lingkungan. Tetapi dalam action-nya terkadang tidak dilakukan karena rasa malas serta tidak peduli dengan lingkungan sekitar. Mengenai protokol kesehatan yang sudah ditetapkan, terdapat pelaksanaan cuci tangan secara teratur. Cuci tangan secara teratur dilakukukan sebagai upaya pelaksanaan menjaga kebersihan diri dan untuk mengurangi risiko tertular virus covid 19. Tanpa kita sadari kedua tangan kita merupakan jalur utama masuknya kuman penyakit ke dalam tubuh karena seringnya menyentuh benda apapun yang belum diketahui kebersihannya. Maka dari itu, cuci tangan secara rutin perlu dilakukan. Hasil wawancara dengan siswa menunjukan bahwa mereka sudah melakukan cuci tangan secara teratur. Hal tersebut dapat dilihat dari distribusi diagram di bawah ini :

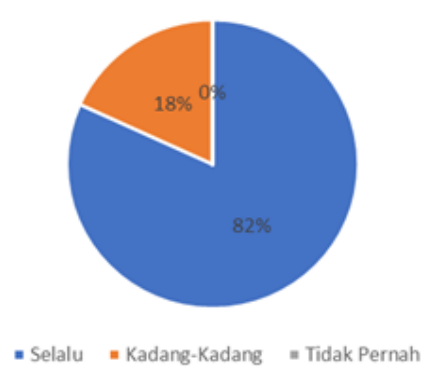

Gambar 2. Diagram Pelaksanaan Cuci Tangan secara Teratur 


\section{Menjaga Jarak}

Menjaga jarak atau social distancing adalah kondisi menjaga jarak dengan orang lain agar tidak terjadi penularan. Dengan situasi pandemi covid 19 seperti saat ini, penerapan jaga jarak sangat penting untuk dilakukan. Bahkan menjaga jarak termasuk ke dalam protokol kesehatan yang sudah ditetapkan oleh pemerintah. Menjaga jarak dapat mengurangi risiko tertular virus dan dapat memutus penularannya. Berikut petikan wawancara peneliti dengan siswa :

IAF : "Jaga jarak itu penting untuk mengurangi risiko tertular virus covid yang dibawa oleh orang lain yang tanpa diketahui kesehatannya".

IB :"Jaga jarak sebagai upaya untuk mengantisipasi terkena virus penyakit yang dibawa oleh orang lain".

WLM :"Jaga jarak itu perlu dilakukan karena kita tidak tahu orang lain membawa virus atau tidak, jadi lebih baik kita menjaga jarak agar tidak terinfeksi”.

Pentingnya menjaga jarak diharapkan kepada siswa untuk diterapkan dengan sebaik-baiknya dan dilakukan secara terus menerus. Supaya jaga jarak tersebut efektif untuk mencegah penularan covid 19. Hasil wawancara peneliti dengan siswa mengenai penerapan jaga jarak menunjukan bahwa siswa kelas XII SMA Negeri 14 Semarang sudah menerapkan jaga jarak tersebut. Hal ini dapat dilihat dari distribusi diagram di bawah ini :

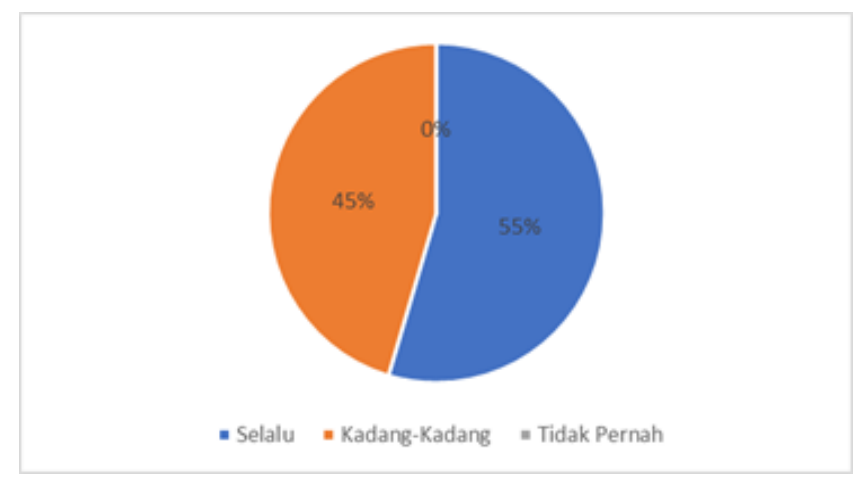

Gambar 3. Diagram Penerapan Jaga Jarak

\section{Mengonsumsi Gizi Seimbang}

Mengonsumsi gizi seimbang menjadi hal yang sangat penting untuk mencukupi segala sesuatu yang dibutuhkan oleh tubuh seperti karbohidrat, protein, lemak, vitamin, mineral, air dan serat dalam jumlah yang tepat. Dalam pelaksanaannya, mengonsumsi gizi seimbang dilakukan dengan cara makan secara teratur, mengonsumsi makanan memenuhi unsur gizi yang lengkap. Berikut petikan wawancara peneliti dengan siswa :

ZFR : "Mengonsumsi gizi yang seimbang itu penting bagi tubuh agar kebutuhan gizinya tercukupi dengan itu kita tidak gampang sakit. Kemudian makan 3x sehari, makan 4 sehat 5 sempurna serta mengurangi konsumsi makanan yang sembarangan"..

DF :"Konsumsi gizi seimbang agar tubuh kita sehat karena gizi yang dibutuhkan oleh tubuh tercukupi. Makan tepat waktu,, makan sayur dan buah dan tidak jajan sembarangan”. 
GAR :"Mengonsumsi gizi seimbang untuk memberikan tubuh gizi yang cukup, jadi tubuh kita memiliki tenaga dan sehat. Makan yg mengandung protein, karbohidrat vitamin".

Mengenai konsumsi makanan yang dilakukan oleh siswa, terdapat konsumsi buah, sayur makanan instan, minum susu, minum suplemen serta minum air putih 6-8 gelas perhari. Pemenuhan gizi bergantung kepada orang tua dalam menyediakan makanan untuk dikonsumsi dan individu itu sendiri. Kaitannya dengan orang tua, pekerjaan serta penghasilan yang didapatkan dapat mempengaruhi apa yang akan diberikan ke anaknya untuk dikonsumsi. Hal ini selaras dengan pernyataan dari Khomsan (2010:11) yang menyatakan bahwa anak-anak yang berasal dari keluarga dengan tingkat sosial ekonomi rendah sangat rawan terhadap gizi kurang. Mereka mengkonsumsi makanan (energi dan protein) lebih rendah dibandingkan dengan anak-anak dari keluarga berada.

\section{Aktivitas Fisik atau Olahraga}

Aktivitas fisik atau olahraga diperlukan untuk menstimulasi sistem pemeliharaan dan perbaikan tubuh secara alami. Secara sederhana dapat dikatakan bahwa aktivitas fisik atau olahraga berkaitan dengan kondisi fisik yang baik. Berikut petikan wawancara peneliti dengan siswa :

BEP :“Olahraga itu penting, karena dengan olahraga bisa menjaga kesehatan dan ketahanan tubuh. Olahraga sebaiknya dilakukan secara rutin”.

SKB :"Aktivitas fisik penting bagi tubuh supaya kuat dan bugar. Dalam melakukan aktivitas fisik diawali dengan pemanasan dan diakhiri dengan pendinginan. Menggunakan peralatan olahraga yang sesuai dan nyaman".

NPM :"Aktivitas fisik ya penting bagi tubuh agar daya tahan tubuh kita kuat dan badan sehat. Olahraga sebaiknya dilakukan secara rutin dan teratur serta dilakukan dengan sungguh-sungguh”.

Aktivitas fisik harus dilakukan dengan baik, benar, teratur dan terukur. Dari hasil wawancara peneliti dengan siswa mengenai aktivitas fisik atau olahraga secara rutin, bisa dilihat dari distribusi diagram di bawah ini :

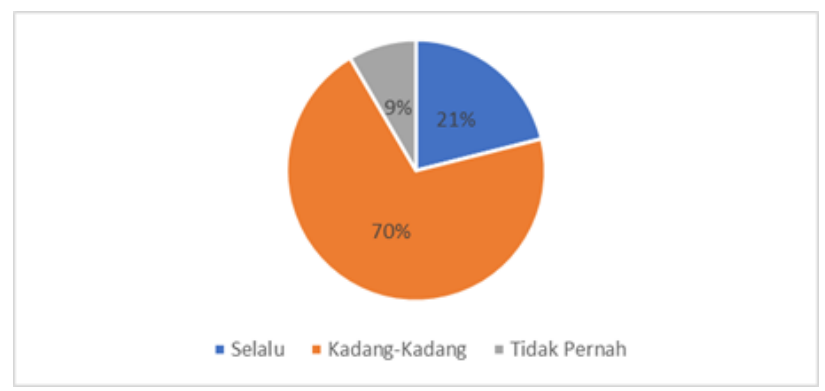

Gambar 4. Diagram Aktivitas Fisik secara Teratur

Beragam jenis aktivitas fisik atau olahraga yang dilakukan oleh siswa di era pandemi covid 19 ini. Dari hasil wawancara peneliti dengan siswa terdapat 14 jenis aktivitas fisik atau olahraga yang dilakukan oleh siswa. Jenis aktivitas fisik atau olahraga yang sering dilakukan oleh siswa adalah jogging, sepeda dan olahraga aplikasi. Jika dilihat aktivitas fisik tersebut bisa dikategorikan ke dalam intensitas sedang. Hal tersebut sesuai dengan anjuran Kemenkes. Menurut Kemenkes (2020) aktivitas 
fisik dan olahraga dalam intensitas sedang dapat meningkatkan imunitas yang sangat diperlukan tubuh saat pandemi covid 19. Dengan imunitas yang tinggi kita bisa mengurangi risiko tertular covid 19.

\section{Istirahat yang Cukup}

Istirahat yang cukup merupakan hal yang penting bagi tubuh dan perlu untuk diterapkan. Peranan istirahat adalah memulihkan kembali kondisi tubuh setelah seharian melakukan aktivitas. Berikut petikan wawancara peneliti dengan siswa :

AW :"Istirahat yang cukup itu penting agar tubuh kita tetap bugar dan tidak merasa kelelahan.

AMS :"Istirahat yang cukup itu penting supaya tubuh bisa beristirahat karena sudah beraktivitas terus bisa fresh di pagi harinya"

FN :"Istirahat yang cukup ya biar memberikan kesempatan buat tubuh untuk beristirahat, jadi bisa memulihkan tenaga dan fit dikeesokan harinya".

Istirahat yang cukup apabila dilakukan dengan benar akan membawa pemulihan dan menambah kekuatan. Istirahat identik dengan melakukan tidur. Dari hasil wawancara, sebagian besar siswa kelas XII SMA Negeri 14 Semarang berada di umur 17 tahun yang artinya membutuhkan waktu tidur 8-9 jam. Berdasarkan wawancara yang dilakukan peneliti dengan siswa mengenai waktu tidur, lebih banyak siswa yang tidur malam kurang dari jam tersebut. Hal ini dapat dilihat dari distribusi diagram di bawah ini :

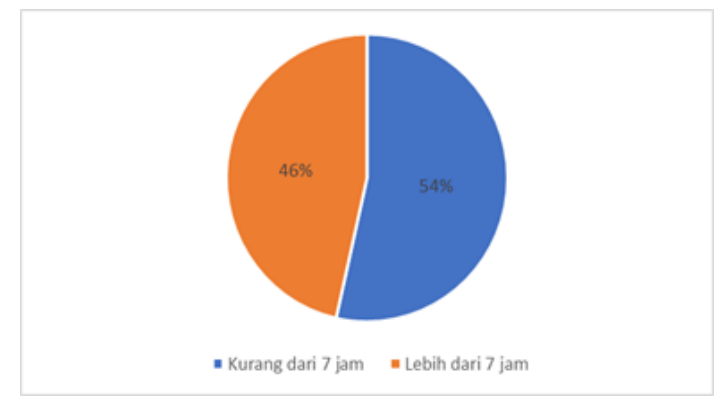

Gambar 5. Diagram Waktu Tidur Siswa

Dari hasil wawancara terdapat beberapa faktor yang membuat siswa susah tidur ketika di malam hari. Tiga faktor terbesar adalah insomnia, tugas sekolah dan gawai.

\section{Rokok dan Alkohol}

Merokok dan mengonsumsi minuman beralkohol akan berdampak bagi tubuh baik secara jangka pendek maupun jangka panjang. Dari hasil wawancara dapat dikatakan bahwa siswa kelas XII SMAN 14 Semarang sudah menyadari bahaya yang didapatkan apabila merokok dan mengonsumsi minuman beralkohol.

Dari hasil wawancara, hanya sebagian kecil siswa yang memiliki kebiasaan merokok. Tetapi bahaya tetap mengintai karena rokok berdampak bagi perokok aktif maupun perokok pasif. Sementara itu, dari hasil penelitian menyatakan bahwa tidak ada siswa yang mengonsumsi minuman beralkohol. Menurut Sanusi (2020:191) menyatakan bahwa terciptanya kualitas hidup yang sehat adalah 
menghentikan gaya hidup yang tidak sehat seperti merokok, alkohol, pola tidur tidak teratur dan tidak aktif secara fisik.

\section{KESIMPULAN}

\section{Kesimpulan}

Berdasarkan hasil penelitian dan pembahasan maka dapat disimpulkan bahwa pada penerapan gaya hidup sehat yang dilakukan oleh siswa kelas XII SMA Negeri 14 Semarang di era pandemi covid 19 sudah berjalan dengan cukup baik. Dari beberapa indikator sudah berjalan dengan baik seperti penggunaan masker, menjaga kebersihan, mengonsumsi gizi seimbang, aktivitas fisik sudah dilakukan oleh sebagian besar siswa. Untuk kebiasaan merokok hanya dilakukan beberapa siswa dan itu artinya sebagian besar siswa tidak merokok. Untuk konsumsi minuman beralkohol, tidak ada siswa yang mengonsumsinya. Tetapi terdapat indikator yang belum maksimal untuk diterapkan seperti penerapan jaga jarak, istirahat yang cukup serta terdapat beberapa siswa yang memiliki kebiasaan merokok.

\section{Saran}

Saran yang dapat diberikan dari penelitian ini adalah bagi guru dan orang tua siswa untuk selalu mengingatkan dan mengawasi penerapan gaya hidup sehat yang dilakukan oleh siswa agar terlaksana dengan maksimal dan saran bagi siswa agar selalu melakukan aktivitas yang menunjang penerapan gaya hidup sehat serta meninggalkan kebiasaan yang dapat menghambat penerapan gaya hidup sehat.

\section{DAFTAR PUSTAKA}

Anhusadar, Laode, dan Islamiyah. 2020. "Penerapan Perilaku Hidup Bersih Dan Sehat Anak Usia Dini Di Tengah Pandemi Covid 19.” Jurnal Obsesi: Jurnal Pendidikan Anak Usia Dini 5(1):463-75.

Ardiyanto, Asep, Veryliana Purnamasari, Sukamto, dan Ekasari Setianingsih. 2020. “Analisis Perilaku Hidup Bersih Dan Status Kebugaran Jasmani Di Era Pandemi Covid-19 Dosen PGSD.”Jendela Olahraga 5(2):131-40.

Arfianto, Yundhi. 2017. "Hubungan Antara Gaya Hidup Sehat Dengan Tingkat Kesegaran Jasmani Siswa Kelas VIII SMP Negeri 1 Sleman.”

Aryanto, Wiwit, dan Sumarjo. 2014. "Hubungan Perilaku Hidup Sehat Dengan Kebugaran Jasmani Siswa kelas Atas Sekolah Dasar Negeri 2 Triwarno Kecamatan Kutowinangun Kabupaten Kebumen.” MEDIKORA XIII(1):12. 
Gratia, Angelina Ave. 2014. "Pengaruh Gaya Hidup Sehat Terhadap Psychological WellBeing Dan Dampaknya Pada Auditor Kap (Studi Empiris Pada Auditor Kantor Akuntan Publik Di Jawa Tengah Dan DIY).”

Khomsan, Ali. 2010. Pangan Dan Gizi Untuk Kesehatan. Jakarta: Rajawali Sport.

Notoatmodjo, Soekidjo. 2010. Ilmu Perilaku Kesehatan. Jakarta: Rineka Cipta.

Ramania, Nia Sri, Sugih Gunawan, Didi Sunadi, dan Kusnaedi. 2019. “Analisis Gaya Hidup Mahasiswa TPB ITB Tahun Ajaran 2018/2019." Jurnal Sains Keolahragaan \& Kesehatan IV(1):15-25.

Sam, Septika Usde Vita. 2018. "Analisis Dampak Pola Hidup Terhadap Kebugaran Pada Siswa Kelas XI IPS 1 SMA Negeri 8 Kota Bengkulu.” 2(1).

Sanusi, Rahmat. 2020. "Identifikasi Gaya Hidup Pra-Lansia Etnis Tionghoa Dalam Menjaga Kesehatan Dan Kebugaran.” Jurnal Endurance : Kajian Ilmiah Problema Kesehatan 5(2):180-93.

Setiyawan, Pandu Kresnapati, dan Danang Aji Setiawan. 2020. "Analisis Perkuliahan Daring Mahasiswa PJKR Universitas PGRI Semarang Sebagai Dampak Pandemi Covid 19.” Edu Sportivo 1(1):25-32.

Sugiyono. 2014. Metode Penelitian Pendidikan ( Pendekatan Kuantitatif, Kualitatif Dan R\&D ). Bandung: Alfabeta.

Tabiin, Ahmad. 2020. "Perilaku Hidup Bersih Dan Sehat (Phbs) Pada Anak Usia Dini Sebagai Upaya Pencegahan Covid 19.” JURNAL EDUKASI AUD 6(1):58-73.

Utama, Lalu Juntra. 2020. “Gaya Hidup Mayarakat Nusa Tenggara Timur Dalam Menghadapi Pandemi Corona Virus Disease 19 (Covid-19).” Jurnal Kesehatan Masyarakat 7(1):34-40.

Wibawa, Nyoman Adi Krisna, dan Putu Nugrahaeni Widiasavitri. 2013. "Hubungan Antara Gaya Hidup Sehat Dengan Tingkat Stres Siswa Kelas XII SMA Negeri Di Denpasar Menjelang Ujian Nasional Berdasarkan Strategi Coping Stres.” Jurnal Psikologi Udayana 1(1):138-50. 